\title{
METODE PEMBELAJARAN QIRA AH PERSEPEKTIF TEORI KOGNITIF SOSIAL ALBERT BANDURA (STUDI KASUS DI SMP MUHAMMADIYAH 2 YOGYAKARTA)
}

\author{
Bintang Rosada1, Muhammad Afif Amrulloh² \\ ${ }^{1}$ UIN Sunan Kalijaga Yogyakarta \\ bintangrosyadah@gmail.com \\ 2UIN Raden Intan Lampung \\ afif.amrulloh@radenintan.ac.id
}

\begin{abstract}
ABSTRAK
Kemahiran membaca menjadi salah satu komponen dalam keterampilan berbahasa Arab dan menjadi tujuan utama dalam pembelajaran bahasa Arab di SMP Muhammadiyah 2 Yogyakarta. Berbagai upaya untuk mewujudkan tujuan tersebut telah dilaksanakan, seperti kelengkapan sarana prasarana, membaca al-Qur'an sebelum memulai pelajaran dan mata pelajaran bahasa Arab masuk dalam intra dan ekstrakurikuler. Akan tetapi, kemampuan membaca siswa kelas IX b siswa sekolah tersebut belum sepenuhnya baik. Berdasarkan fakta tersebut peneliti ingin mengetahui implementasi metode pembelajaran qira'ah siswa kelas IX $b$ SMP Muhammadiyah 2 Yogyakarta dengan empat konsep dalam teori pembelajaran Albert Bandura. Penelitian dilakukan dengan menggunakan pendekatan kualitatif. Sedangkan jenis penelitiannya adalah kualitatif, bersifat deskriptif dalam pembelajaran qira'ah dengan teori kognitif sosial Albert Bandura. Analisis yang digunakan adalah analisis deskriptif. Peneliti menggunakan metode pengumpulan data secara triangulasi yang menggabungkan berbagai teknik pengumpul data. Sedangkan jenis penelitian ini termasuk penelitian lapangan (field research). Hasil dari penelitian ini menunjukkan bahwa implementasi pembelajaran qira'ah di kelas tersebut menggunakan empat konsep pembelajaran teori kognitif sosial Albert Bandura mencakup atensi, retensi, produksi dan motivasi. Penerapan konsep tersebut memberikan dampak terhadap kelancaran pembelajaran qira'ah.
\end{abstract}

Kata Kunci : Albert Bandura, Kognitif, Maharah Qira’ah.

\section{ABSTRACT}

Reading skills became one of the components in Arabic skills and became the main objective in learning Arabic in SMP Muhammadiyah 2 Yogyakarta. 
Various efforts to realize these objectives have been implemented, such as the completeness of infrastructure facilities, reading the Koran before starting the lesson and the subjects of Arabic language entered in intra and extracurricular. However, the ability to read students in grade IX $b$ school students is not yet fully good. Based on these facts the researcher wanted to know the implementation of learning method of qira'ah student of class IX b SMP Muhammadiyah 2 Yogyakarta with four concepts in Albert Bandura learning theory. The research was conducted using qualitative approach. While the type of research is qualitative, is descriptive in learning qira'ah with social cognitive theory Albert Bandura. The analysis used is descriptive analysis. Researchers used a method of collecting data in triangulation that combines various techniques of data collection. While this type of research including field research (field research). The results of this study indicate that the implementation of learning qira'ah in the class using four concepts of learning social cognitive theory Albert Bandura include attention, retention, production and motivation. Application of the concept has an impact on the smoothness of learning qira'ah.

Keywords : Albert Bandura, Kognitif, Maharah Qira'ah. 


\section{PENDAHULUAN}

Bandura merupakan nama dari seorang ahli psikologi yaitu Albert Bandura. Albert Bandura sangat terkenal dengan teori pembelajaran sosialnya yang merupakan salah satu konsep dalam aliran behaviorisme yang menekankan pada komponen kognitif dari pemikiran, pemahaman dan evaluasi (Sri Lestari, 2014: 4). Teori kognitif sosial yang dikemukakan oleh Albert Bandura menyatakan, bahwa faktor sosial dan kognitif serta faktor pelaku memainkan peran penting dalam pembelajaran. Faktor kognitif berupa ekspektasi/ penerimaan siswa untuk meraih keberhasilan, faktor sosial mencakup pengamatan siswa terhadap model. maka ketika siswa belajar mereka dapat merepresentasikan atau mentransformasikan pengalaman mereka secara kognitif sehingga adanya peniruan (Sri Lestari, 2014: 3).

Menurut Syamsuddin Asyrofi, metode qirā'ah merupakan cara menyajikan pelajaran dengan cara membaca dan memahami isi bacaan, didahului oleh pengenalan kosakata pokok dan maknanya, kemudian mendiskusikan isi bacaan dengan bantuan guru (Syamsudin Asyrofi, 2016: 93). Metode qirā'ah ini tidak terlepas dari empat kegiatan yang tercakup dalam teori Albert Bandura, artinya siswa mengamati, meniru dan memproduksi apa yang dicontohkan oleh guru sebagaimana yang terjadi di kelas IX b SMP Muhammadiyah 2 Yogyakarta (Syamsudin Asyrofi, 2016: 93). Bahwa proses pembelajaran dimulai dengan modelling atau pembelajaran observasional yang mencakup aspek atensi/perhatian, retensi/pemertahanan, produksi/praktik dan motivasi.

Kemahiran membaca sebagai salah satu keterampilan bahasa Arab dijadikan tujuan utama dalam pembelajaran bahasa Arab di SMP Muhammadiyah 2 Yogyakarta. Hal ini dibuktikan dengan adanya beberapa kegiatan baik intrakurikuler maupun ekstrakurikuler seperti: PBHA (Pemberantasan Buta Huruf AI-Quran) yang mencakup tahsin, tahfidz, qirā'ah, dan pidato. Selain itu, terdapat sarana dan prasarana yang menunjang siswa untuk menguasai empat keterampilan bahasa Arab, khususnya keterampilan dalam membaca, seperti: laboratorium bahasa dan LCD proyektor. Bedasarkan hasil wawancara awal, bahwa siswa SMP Muhammadiyah 2 Yogyakarta diwajibkan untuk membaca al-Quran selama 20 menit sebelum pelajaran dimulai dan hal ini dilakukan secara terus menerus dengan dibimbing oleh wali kelas masing-masing. Dari sini, penulis yakin siswa SMP Muhammadiyah 2 Yogyakarta khususnya kelas IX b, sangat mungkin dapat menguasai kemahiran membaca teks berbahasa Arab dengan baik dan benar. Di samping itu, siswa kelas IX b SMP 
Muhammadiyah 2 Yogyakarta telah mendapat pelajaran bahasa Arab baik intrakurikuler maupun ekstrakurikuler sejak kelas VII. Pada kenyataannya, Penulis melihat bahwa kemahiran membaca siswa kelas IX b SMP Muhammadiyah 2 Yogyakarta belum sepenuhnya dapat dikatakan baik. Bedasarkan hal tersebut, penulis ingin meneliti implementasi metode pembelajaran qirā'ah siswa kelas IX b SMP Muhammadiyah 2 Yogyakarta dengan empat konsep dalam teori pembelajaran Albert Bandura. Maka fokus penulisan ini adalah mendeskripsikan aspek atensi, retensi, produksi dan motivasi, dalam pembelajaran qirā'ah siswa kelas IX b SMP Muhammadiyah 2 Yogyakarta dengan teori kognitif sosial Albert Bandura.

\section{LANDASAN TEORI}

Pembelajaran sosial merupakan proses pembelajaran atau perilaku yang dibentuk melalui konteks sosial, teori ini dikembangkan oleh Albert Bandura. Teori kognitif sosial yang menonjolkan gagasan bahwa sebagian besar pembelajaran manusia terjadi dalam sebuah lingkungan sosial. Dengan mengamati orang lain, manusia memperoleh pengetahuan, aturan-aturan, keterampilan-keterampilan, strategi-strategi, keyakinan-keyakinan dan sikap-sikap (Dale H. Schuck, 2012: 161). Albert Bandura mengatakan bahwa seseorang dapat belajar melalui pengamatan terhadap suatu model. Model yang dimaksud adalah orang tua dan guru sebagai pendidik utama, teladan atau panutan yang akan dilihat dan dicontoh anak (Helmawati, 2016: 144). Maka model hendaknya menarik, dapat dipercaya, sesuai dengan kelompok dan memiliki standar performa. Seperti halnya guru dapat dijadikan model bagi siswanya karena dipercaya memiliki pengetahuan yang mendalam. Selain itu, teori kognitif sosial juga menggambarkan sebuah aplikasi pemodelan dalam pengajaran, bahwa seseorang dapat belajar melakukan sesuatu hanya dengan mengamati dan mengulang apa yang ia lihat. Maka dari itu, teori kognitif social Albert Bandura sering dinamakan dengan pembelajaran observasional atau modelling, yakni pembelajaran yang dilakukan ketika seseorang mengamati dan meniru perilaku orang lain (John W.Santrock, 2004: 286). Menurut Dale H.Schunk, Paul R.Pintrich dan Judith L.Meece bahwa Pembelajaran observasional mencakup empat proses, yakni: perhatian (atensi), pemertahanan (retensi), produksi dan motivasi (Dale H. Schuck, 2012: 196). 
Keterampilan membaca (maharah Qirā'ah ) adalah menyajikan materi pelajaran dengan cara lebih dulu mengutamakan membaca, yakni guru mula-mula membacakan topik-topik bacaan, kemudian diikuti oleh para siswa (Syaiful Mustofa, 2011: 162). Membaca tidak sekedar mengubah lambang tulis menjadi bunyi, akan tetapi juga mengambil informasi yang terkandung dalam teks bacaan. Maka, perlu adanya metode yang tepat yang dapat digunakan dalam kegiatan pembelajaran Qirā'ah. Menurut Syaiful Mustofa Metode adalah cara mengajar yang digunakan oleh pengajar dalam sebuah proses pembelajaran bahasa agar tercipta tujuan yang ingin dicapai (Syaiful Mustofa, 2011: 13). Jadi, metode merupakan cara mengajar yang harus digunakan dan disesuaikan dengan tujuan pembelajaran guna memudahkan guru dalam menyampaikan informasi kepada siswa. Terdapat berbagai langkahlangkah penyajian pada metode pembelajaran qirā'ah yang ditegaskan oleh berbagai ilmuan, diantaranya Wa Muna, Ulin Nuha, Ahmad Izzan, Abd.Wahab Rosyidi, Mamlu'atul Ni'mah dan lain sebagainya. Penulis melihat bahwa terdapat kesamaan antara kelimanya dalam menyajikan langkah-langkah pada metode pembelajaran qirā'ah, yakni pembelajaran qirā'ah dimulai dengan mengikuti bacaan seorang guru dan latihan-latihan pengucapan. Hal tersebut juga berlaku pada pembelajaran qirā'ah siswa kelas IX b SMP Muhammadiyah 2 Yogyakarta, maka dari itu, implementasi metode pembelajaran qirā'ah siswa kelas IX b SMP Muhammadiyah 2 Yogyakarta dan empat konsep dalam teori pembelajaran Albert Bandura sama-sama diawali dengan cara mengamati dan meniru.

\section{METODE PENELITIAN/ EKSPERIMEN}

Jenis penulisan yang digunakan adalah penulisan lapangan (field research) yang bersifat deskriptif dengan pendekatan kualitatif, Peneliatian ini difokuskan pada metode pembelajaran qirā'ah di kelas IX b SMP Muhammadiyah 2 Yogyakarta. Kemudian, metode pembelajaran qirā'ah di kelas IX b SMP Muhammadiyah 2 Yogyakarta dianalisis secara mendalam dengan teori kognitif sosial Albert Bandura.

Analisis yang digunakan adalah analisis deskriptif, berupa deskripsi/ gambaran secara sistematis, faktual dan akurat mengenai fakta-fakta, sifat-sifat serta hubungan antara fenomena yang diselidiki, yaitu tentang metode pembelajaran qirā'ah.

Penulisan ini dilakukan secara indukif. Penulisan ini dilakukan di SMP Muhammadiyah 2 Yogyakarta. Metode pengumpulan data digunakan secara triangulasi, yakni tehnik pengumpulan data yang bersifat menggabungkan dari 
berbagai tehnik pengumpulan data dan sumber yang sudah ada (Sugiyono, 2008: 330), seperti observasi, wawancara mendalam dan dokumentasi. Proses analisis data dilakukan melalui beberapa tahapan, yakni mulai dari proses reduksi data, penyajian data dan verifikasi.

\section{HASIL DAN PEMBAHASAN}

Pada hasil penelitian ini, penulis memfokuskan pada metode pembelajaran qirā'ah dengan sudut pandang teori kognitif sosial Albert Bandura yang mencakup empat tahapan yaitu atensi, retensi, produksi dan motivasi. Pada umumnya, jenis qirā'ah ada dua, yaitu qirā'ah jahriyah dan qirā'ah shāmitah. Di kelas IX b lebih banyak menggunakan qirā’ah jahriyah dari pada qirā’ah shāmitah. Hal tersebut dikarenakan qirā'ah jahriyah selain lebih mudah diterapkan bagi siswa kelas IX b, juga mudah untuk mengevaluasinya. Dengan kata lain, qirā'ah jahriyah dipilih karena di kelas IX b SMP Muhammadiyah 2 Yogyakarta belum menerapkan qirā'ah shāmitah sepenuhnya, mengingat latar belakang siswa yang berbeda- beda baik dari segi tamatan maupun kemampuan. Ada tiga pembagian kelas di SMP Muhammadiyah 2 Yogyakarta, yaitu: reguler, akselerasi dan bilingual. Kelas IX b merupakan kelas reguler yang terdiri dari delapan kelas $(\mathrm{A}-\mathrm{H})$. Adapun metode pembelajaran qirā'ah pada mata pelajaran bahasa arab yang diterapkan di kelas IX b SMP Muhammadiyah 2 Yogyakarta dengan perspektif Albert Bandura adalah sebagai berikut:

Atensi (perhatian), pada tahap ini, pembelajaran dimulai dengan memusatkan perhatian siswa, maka guru kelas memulai dengan appersepsi yang menyenangkan, seperti:

A. Menggerakan Anggota Badan, Menanya Kabar Siswa: Guru masuk kelas kemudian mengamati keadaan siswa, lalu guru menyuruh seluruh siswa berdiri untuk menggerakkan badan, setelah itu, guru menyuruh antar siswa saling memukul pundak temannya dengan pukulan yang ringan. Hal ini dilakukan untuk merelaxkan otot-otot tubuh. Kemudian,Guru meminta siswa yang mengantuk untuk mencuci muka atau berwudhu. Merelaxkan otot-otot tubuh sangat penting, mengingat proses pembelajaran qirā'ah melibatkan banyak panca indera seperti telinga, mulut, dan konsentrasi,

B. Pengucapan Salam: Sebelum pelajaran di mulai, kegiatan pertama yang dilakukan oleh guru adalah memberi salam kepada siswa dengan menggunakan suara yang keras, hal ini untuk mengawali pembelajaran dengan 
semangat. Jika guru merasa tidak puas dengan jawaban siswa, guru mengulangi salam sampai beberapa kali sampai siswa menjawab salam guru dengan semangat,

C. Bertanya: Guru memberikan pertanyaan tentang penjelasan yang telah diberikan kepada salah seorang siswa, hal ini digunakan guru untuk menyambungkan pemahaman lama dengan pemahaman baru mengenai materi yang dipelajari. Misalnya pada materi yang berjudul "الطالب النشيط", guru memberikan pertanyaan yang berasal dari latihan-latihan yang terdapat dalam buku cetak kepada siswa, seperti متى يستيقظ محمد من النوم؟. selain itu, guru juga meminta kepada salah satu siswa untuk menerjemahkan kalimat yang terdapat dalam materi yang telah dijelaskan sebelumnya, seperti guru meminta salah satu siswa menerjemahkan arti dari "محمد طالب نشبط".

D. Mengubah Tempat Duduk: Mengubah tempat duduk siswa merupakan salah satu persiapan yang dilakukan guru sebelum memulai pembelajaran, hal ini bertujuan untuk meminimalisir gangguan yang dapat merubah konsentrasi dan perhatian siswa, seperti siswa yang memiliki kemampuan lebih baik diantara teman-temannya akan disatukan dengan siswa yang masih memerlukan bimbingan belajar, siswa yang berpotensi membuat kegaduhan dipindahkan ke barisan terdepan, dan siswa yang sering kali mengobrol dengan teman sebangkunya dipisahkan dan disatukan dengan siswa pendiam.

Retensi (pemertahanan) Tahap ini adalah proses bagaimana siswa mengodekan informasi kemudian menyimpannya ke dalam memori, setiap siswa mempunyai cara masing-masing dalam mengodekan suatu informasi yang didapat. Karena terdapat beberapa penjelasan model (guru) yang tidak bisa dijelaskan dengan kata-kata maka siswa dapat mengodekannya dengan bentuk verbal atau visual, seperti:

A. Pemberian Contoh: Bila memungkinkan, sebelum memulai pembelajaran qirā'ah di kelas IX b, guru memberikan contoh bacaan teks berbahasa arab dari awal paragraf sampai ahir paragraf, akan tetapi hal tersebut dilakukan menyesuaikan waktu yang ada. Sebagaimana diketahui bahwa pelajaran bahasa arab di kelas IX b hanya diberikan sekali dalam seminggu dengan durasi 40 menit. Misalnya pada materi "الطالب النشيط".

$$
\begin{aligned}
& \text { ( (1) محمد طالب نثيط/ هو يدرس فى المدرسة المتوسطة المحمدية يوجياكرت فى الصف التاسع/ يستيقظ من }
\end{aligned}
$$

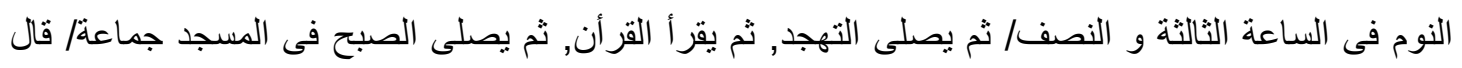


74 | Jurnal Tarbawi Vol. I5. No. I. Januari - Juni 2018

رسول الله ص.م: صلاة الجماعة أفضل من صلاة الفذ بسبع و عشرين درجة (متفق عليه)/ و بعد الصلاة يتعلم دروسا.

B. Rehersial (Pengulangan Informasi): Pengulangan informasi sangat penting untuk mempertahan informasi yang akan disimpan siswa, hal inilah yang selalu dilakukan guru bahasa arab di kelas IX $b$, dimana guru selalu mengulang bacaan teks secara kata perkata dengan berulang-ulang. Hal tersebut dimaksudkan agar siswa kelas IX b mudah mengikuti ucapan guru dan dapat mengingat bacaan tersebut. Misalnya pada materi "القرأن الكريم", yakni:

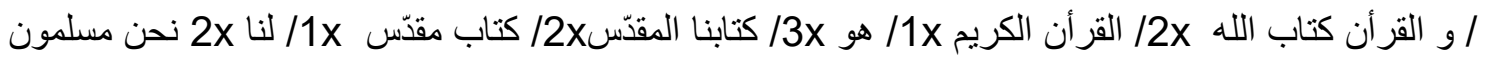

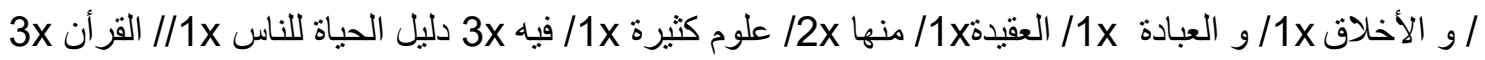

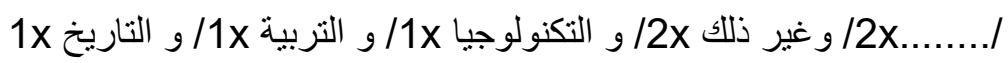

Guru membaca teks kata perkata diikuti oleh siswa dan menyertakan arti kataperkata secara beriringan.

C. Mengaitkan Informasi Baru Dengan Informasi Lama: Guru selalu menjelaskan materi baru dengan mengaitkan materi yang telah dipelajari dan menjelaskan teks bacaan dengan mengaitkannya langsung dalam kehidupan siswa. Misalnya pada materi "القرأن الكريم", sesudah membaca teks tersebut, guru menjelaskan kandungan teks dengan bercerita tentang fadhilah membaca alQuran dan menghubungkannya langsung dengan kehidupan siswa.

D. Elaborasi (Perluasan atau Perincian): Guru menggunakan elaborasi untuk memperdalam pengetahuan dan memudahkan pemahaman siswa, dengan cara menggunakan pengetahuan lama untuk memperdalam pengetahuan baru sehingga terjadi keterkaitan antara pengetahuan lama dan baru, misalnya terdapat kata-kata "مدرسة", untuk mempertajam ingatan dan pemahaman siswa akan kata "ددرسة", maka kata tersebut dapat dianalogikan dengan menggunakan kata-kata yang telah diketahui siswa, yaitu مدرسة الثانوية, مدرسة المتوسطة, محمد طالب فى المدرسة الثانوية, مدرسة كبيرة, مدرسة جميلة.

E. Peta Konsep: Peta konsep merupakan salah satu cara yang digunakan guru untuk mempermudah siswa kelas IX b SMP Muhammadiyah 2 Yokyakarta dalam mempelajari qawā'id dan materi yang dipelajari. Qawā'id sangat penting untuk dipelajari ketika siswa ingin memahami teks yang dibaca, karena masih banyak siswa kelas IX b yang keliru dalam memahami perubahan kata ketika kata ganti dan subjek (pelaku) berbeda di dalam teks bacaan. 
F. Pengorganisasian Kata: Dalam pembelajaran qirā'ah di kelas IX b SMP Muhammadiyah 2 Yogyakarta, guru menuliskan beberapa kaidah yang terkait dengan nahwu dan shorof di papan tulis, serta mengelompokkannya menjadi beberapa bagian guna memudahkan siswa dalam memahaminya, misalnya pada pembelajaran nahwu, guru mengelompokkan contoh fi'il mudhōri' yang sedang dipelajari dengan fi'il madhi yang telah dipelajari.

G. Kata Kunci: guru membuat kata kunci untuk mengidentifikasi fi'il mudhōri' dalam

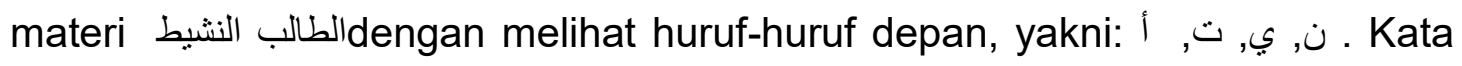
kerja yang diawali dengan huruf ي dapat diartikan dia laki-laki, kata kerja yang diawali dengan huruf $ت$ dapat diartikan dia perempuan. Kata kerja yang diawali dengan huruf ن dapat diartikan kita, kata kerja yang diawali dengan huruf dapat diartikan saya.

Produksi (praktik) adalah proses dimana seorang anak dapat memperaktikkan informasi yang telah didapatkan. Artinya proses menerjemahkan bentuk simbolis suatu perilaku yang dimodelkan ke dalam perilaku yang nyata, maka produksi dapat mencakup pemanggilan kembali apa yang diingat. Untuk mengetahui kemampuan siswa kelas IX b menerjemahkan bentuk simbolis suatu perilaku yang dimodelkan ke dalam perilaku yang nyata, maka tidak cukup dengan memberikan latihan-latihan. Pada tahap ini guru juga menggunakan berbagai cara untuk melihat umpan balik yang diberikan siswa kelas IX b, seperti:

A. Latihan Tertulis, Lisan dan Praktik: siswa kelas IX b diminta mengerjakan soal latihan yang tertulis di dalam buku cetak seperti menerjemahkan(1), memilih jawaban yang benar(2), mengidentifikasi kata kerja tertentu dalam suatu kalimat(3), menjawab pertanyaan(4), mengisi kolom(5). Selain latihan tertulis, guru mengajukan pertanyaan kepada siswa secara individual, hal ini juga untuk melihat pemahaman siswa akan teks bacaan. Biasanya pertanyaan yang diberikan oleh guru berasal dari pertanyaan-pertanyaan pada latihan di dalam buku cetak. Praktik adalah salah satu umpan balik yang diberikan guru untuk melihat kemampuan siswa dalam membaca teks dengan benar. sesekali guru mengetes bacaan siswa baik di tengah pembelajaran maupun di akhir pembelajaran.

B. Tugas Kelompok: guru memberikan tugas secara berkelompok untuk melihat kemampuan siswa menerjemahkan bentuk simbolis suatu perilaku yang dimodelkan ke dalam perilaku yang nyata. Selain untuk melihat kemampuan

> | Bintang Rosada dan Muhammad Afif Amrulloh | Metode Pembelajaran Qira'ah Persepektif Teori Kognitif Sosial Albert Bandura (Studi Kasus di SMP Muhammadiyah 2 Yogyakarta) 
siswa, tugas kelompok juga dijadikan sebagai pembelajaran di luar kelas karena keterbatasan waktu untuk menjelaskan kaidah-kaidah dalam bahasa arab seperti nahwu dan shorof.

C. Pekerjaan Rumah: Guru selalu memberikan PR kepada setiap siswa di kelas IX b setiap akhir pelajaran. Adapun PR yang diberikan berupa soal-soal yang terdapat dalam buku cetak, seperti: menerjemahkan, memilih jawaban yang benar, mengidentifikasi kata kerja tertentu dalam suatu kalimat, menjawab pertanyaan, mengisi kolom.

Motivasi (penguatan) Motivasi merupakan proses ke empat dalam pembelajaran observasional. Motivasi yang dimaksud dalam pembelajaran berupa dorongan dan alasan-alasan tertentu yang mendorong siswa untuk melakukan peniruan. Dengan motivasi dapat membantu siswa mengarahkan perhatian dan mempengaruhi bagaimana informasi diproses, maka motivasi mencakup dorongan baik dari dalam diri siswa maupun dari luar diri siswa, baik dorongan positif maupun negative. Artinya, motivasi tidak harus berupa dukungan atau sesuatu yang disukai, akan tetapi motivasi juga dapat berupa sesuatu yang merugikan atau tidak disenangi. Sebagaimana di kelas IX b SMP Muhammadiyah 2 Yogyakarta, guru selalu memotivasi siswa berupa:

A. Imbalan: Di kelas IX b SMP Muhammadiyah 2 Yogyakarta guru selalu memberikan imbalan terhadap siswa yang dapat membaca dengan baik dan benar, dapat menjawab pertanyaan dengan benar, dapat menjelaskan isi materi terhadap temannya, dan dapat membenarkan jawaban teman yang salah. Imbalan yang diberikan oleh guru adalah dengan memberikan sejumlah nilai terhadap kemampuan siswa.

B. Perbandingan Sosial: Di kelas IX b SMP Muhammadiyah 2 Yogyakarta, guru menjadikan salah satu siswa sebagai siswa teladan bagi temannya karena keterbatasan dan semangatnya dalam mengikuti pembelajaran qirā'ah. Meskipun mempunyai keterbatasan, namun siswa tersebut terlihat lebih semangat dan antusias ketika menjawab pertanyaan guru, mengikuti bacaan guru,dan bertanya, dari pada siswa lainnya. Hal ini menambahkan kepercayaan diri bagi siswa yang menjadi siswa teladan dan juga menjadi motivasi bagi siswa lainnya untuk meniru semangat temannya dalam mengikuti pembelajaran qirā'ah. 
C. Penanggung Jawab: Cara untuk memotivasi siswa kelas IX b yang kurang semangat dalam mengikuti proses pembelajaran qirā'ah, guru menjadikan siswa tersebut sebagai penanggung jawab untuk mengumpulkan tugas tertulis teman-temannya, membagikan buku latihan yang telah dikoreksi oleh guru, mengumumkan informasi yang berasal dari guru kepada teman-temannya. Hal tersebut dimaksudkan untuk menumbuhkan kepercayaan diri dan keyakinan pada diri siswa, bahwa ia memiliki nilai lebih dimata sang guru.

D. Hukuman: Hukuman yang diberikan guru kepada siswa bertujuan untuk memotivasi agar siswa menghindari perbuatan yang dapat menimbulkan hukuman dan memberikan efek jera terhadap siswa. Namun, hukuman yang diberikan guru kepada siswa haruslah bersifat mendidik, artinya hukuman dapat menjadikan siswa menjadi pribadi yang lebih baik, seperti: menghafal, mengerjakan soal, atau membuat rangkuman.

E. Pujian: Di kelas IX b SMP Muhammadiyah 2 Yogyakarta, guru selalu memuji siswa kelas IX b apabila dapat memberikan jawaban yang tepat, membenarkan bacaan temannya yang salah, dan dapat menjelaskan arti kosakata. Hal ini dilakukan guru untuk memberikan motivasi agar siswa tetap semangat dalam mengikuti pelajaran bahasa arab dan mempunyai kepercayaan diri. Pujian yang diberikan guru berupa ucapan yang baik dan acungan jempol dengan wajah tersenyum, sambil berkata "Ya! Bagus! Pinter..." dan "muridnya pintar gurunya tidak, tapi sangat-sangat pintar!”.

F. Penggunaan Metode Pembelajaran Yang Bervariasi: Penggunaan metode pembelajaran yang bervariasi merupakan salah satu cara yang dapat digunakan guru untuk menghindarkan siswa dari rasa jenuh saat mengikuti proses pembelajaran. sebagaimana yang dilakukan oleh guru bahasa arab yang mengajar siswa kelas IX b SMP Muhammadiyah 2 Yogyakarta. Guru menggunakan berbagai metode yang dapat membangkitkan semangat siswa dan menghindarkan siswa dari rasa jenuh, seperti: metode qirā’ah (membaca), qawāid wa tarjamah (tata bahasa dan terjemah), as-Sami'yah asy-Syafawiyah (dengar ucap), metode eklektik (campuran), dan al-Muhākat wal istizhār (meniru dan menghafal).

Empat aspek dalam proses pembelajaran observasional yang diusung oleh Albert Bandura sangat sesuai dengan apa yang terjadi dalam metode pembelajaran qirā'ah di kelas IX b SMP Muhammadiyah 2 Yogyakarta, di mana guru memulai 
pelajaran dengan memusatkan perhatian siswa dengan tampilan yang menyenangkan, dilanjutkan dengan pemberian contoh pelafalan kata perkata dan kalimat perkalimat sesuai teks yang dipelajari, agar diikuti oleh seluruh siswa. Tak cukup sampai di situ, guru memberikan umpan balik berupa pertanyaan, latihan tertulis dan praktik langsung, guna melihat kemampuan siswa dalam membaca teks berbahasa arab dengan baik dan benar serta pemahaman siswa kelas IX $\mathrm{b}$ akan teks bacaan. Di ahir, pertengahan atau awal pembelajaran, guru tak lupa memberikan dorongan atau penguatan berupa motivasi yang dikaitkan langsung dengan kehidupan siswa, kesenangan siswa, harapan siswa dan cita-cita siswa

\section{KESIMPULAN}

Penerapan metode pembelajaran qira'ah persepektif Teori Kognitif Sosial Albert Bandura ini memberi sumbangan terhadap para pengajar dalam pengajaran bahasa Arab, khususnya pembelajaran qira'ah. Kajian tentang metode pembelajaran qira'ah ini, sebaiknya muncul penelitian yang lebih mendalam lagi guna meningkatkan pembelajaran qira'ah yang lebih baik.

\section{DAFTAR PUSTAKA}

Dale H Schunk, Paul R.Pintrich dan Judith L. Meece. 2012. Motivasi Dalam Pendidikan; Teori, Penulisan dan Aplikasi. Jakarta: PT. Indeks

Dale H. Schunk .2012. Learning Theories An Educational Perspective terj. Eva Hamdiah dan Rahmat Fajar. Yogyakarta: Pustaka Pelajar

Helmawati. 2016. Pendidik Sebagai Model. Bandung: PT. Remaja Rosdakarya John W. Santrock, Psikologi Pendidikan terj. Tri Wibowo. 2004. Jakarta: Kencana Sri lesatari, L.Ade, MD.Sumantri dan KD.Suartama, "Pengaruh Model Pembelajaran Bandura Terhadap Kinerja IImiah dan Hasil Belajar IPA Siswa Kelas IV SD," Jurnal Mimbar PGSD Jurusan PGSD, Universitas Pendidikan Ganesha, Vol. 2, No. 1, Tahun 2014.

Sugiyono. 2008. Memahami Penulisan Kualitatif. Bandung: Alfabeta

Syaiful Mustofa. 2011. Strategi Pembelajaran Bahasa Arab Inovatif. Malang: Uin Maliki Press

Syamsuddin Asyrofi. 2016. Metodologi Pengajaran Bahasa Arab; Konsep dan Implementasinya. Yogyakarta: Ombak. 